International Journal of Social and Administrative Sciences

$\operatorname{ISSN}(e)$ : 2521-0556

DOI: 10.18488/journal.136.2018.32.105.112

Vol. 3, No. 2, 105-112

(C) 2018 AESS Publications. All Rights Reserved.

URL: www.aessweb.com

check for
updates

\title{
POLICY DEVELOPMENT OF THE CHILD-FRIENDLY CITY: CASE STUDY OF SOUTH TANGERANG CITY REGIONAL GOVERNMENT
}

\section{Evi Satispi ${ }^{1}$}

\author{
${ }^{\prime}$ Faculty of Social and Political Sciences, University of Muhammadiyah \\ Jakarta, Indonesia \\ Email:evi.satispi@umjac.id
}

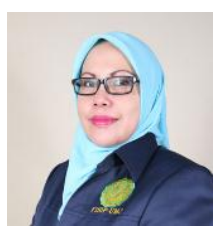

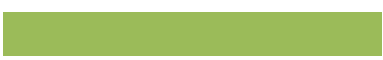

Article History

Received: 8 October 2018 Revised: 12 November 2018 Accepted: 18 December 2018 Published: 2 January 2019

\section{Keywords}

Policy development Child-Friendly city in South Tangerang city government

\begin{abstract}
This study aims to find out the Policy Development of the City of South Tangerang to implement the Ministerial Regulation of the Women's Empowerment and Child Protection of the Republic of Indonesia Number 11 of 2011, regarding the ChildFriendly City Development Policy using a qualitative approach and descriptive research methods. That is to explain phenomena in depth through data collection. This type of research provides an overview, an accurate explanation objectively about the actual state of the object under study. Research design uses the theory of public policy making according to Metter and Horn. The results of the South Tangerang development research generally went well. Among them; achievement of basic health and welfare, the large number of breastfeeding facilities and breastfeeding corners, high percentage of complete basic immunizations for children, low prevalence of malnutrition in children under five, low infant mortality rate (IMR), as well as active and outstanding ARHCIC (Adolescent Reproductive Health Counseling Information Center).
\end{abstract}

Contribution/ Originality: This study is one of the very few studies which have investigated the development of the child-friendly city. Evaluation of the child- friendly city development policy in South Tangerang has generally been going well based on the policy objectives and fulfillment of most the right of children based on the Convention on the Right of the Child.

\section{INTRODUCTION}

A child is a person who is not yet 18 (eighteen) years old, including those who are still in the womb (Regulation of the State Minister for Women's Empowerment and Child Protection Number 11 of 2011, concerning ChildFriendly City Development Policy (KLA). developed to be able to participate actively in development, therefore, it is important to foster the child's mentality and morality out of the Ministry of Women's Empowerment and Child Protection No. 11 of 2011, concerning the Child Friendly City Development Policy, which has been categorized as KLA has a development system based on children's rights through a comprehensive and sustainable integration of commitment and resources of government, society and business world in policies, programs and activities to ensure the fulfillment of children's rights, meaning that there are three elements involved, namely: Government, community, and business. 
To facilitate the classification of the fulfillment of children's rights, the grouping of indicators is divided into six parts, which include the institutional strengthening section and 5 (five) children's rights clusters, namely: (1) Civil rights and freedom; (2) Family environment and alternative care; (3) Basic health and welfare; (4) Education, utilization of leisure time and cultural activities; (5) Special Protection

Banten Regional Government (Pemda) Province of Indonesia is one of the Republic of Indonesia's Republic of Indonesia buffer regions which has a lot of potential for development. Development in various sectors must be balanced with the fulfillment of children's rights. Therefore the quality of children is a determinant of the sustainability and success of development in the future. Of the eight districts/cities in the Banten Regional Government, only South Tangerang City has received the KLA award from the Ministry of Women's Empowerment and Child Protection. South Tangerang City is one of 37 districts and cities that received the KLA award in the Pratama category.

As a form of institutional strengthening in the implementation of the KLA Development Policy in South Tangerang, South Tangerang Mayor Decree Number 463 / Kep-185-Huk / 2011 was made concerning the ChildFriendly City Task Force of South Tangerang City. There is also the Regional Regulation of South Tangerang City Number 3 of 2012, concerning Protection of Women and Children Victims of Violence. This proves the seriousness of the South Tangerang City Government in making regulations that regulate the guarantee of children's rights. In addition, some of the fulfillments of children's rights in Tangsel City have also been good. One of them is the fulfillment of children's rights for educational clusters, the use of leisure time and cultural activities, namely the high rate of participation in early childhood education in the City of Tangsel, judging by the number of pre-school institutions in South Tangerang City. This which later became an added value in the assessment of South Tangerang City won the first level of Child-Friendly Regency / City (KLA) award.

Even so, the implementation of the KLA development policy in South Tangerang City does not just run smoothly, there are problems including the number of children whose civil rights have not been fulfilled, namely many who do not have a birth certificate, lack of government attention to some facilities and infrastructure development towards the City Layak Anak (KLA), can be seen from the lack of quantity and quality of the Safety School Zone (ZoSS). In fact, the existence of ZoSS is considered to be very effective in preventing accidents, especially for students who are still in elementary school, the Regional Government of South Tangerang City does not have a shelter for rehabilitation for street children. Thus, street children who are netted are only recorded, without any rehabilitation efforts. So that way the Regional Government of South Tangerang City has not been able to alleviate street children problems completely. Of the approximately 50 institutions in Tangsel City including the Childcare Social Institution, all are managed by the private sector. Lack of active role of the Child Protection Task Force (PA Task Force) at the RW level in conducting socialization and counseling in preventing cases of domestic violence (domestic violence) including violence against children. In accordance with article 4 of Law No.23 of 2002 concerning Child Protection, that every child has the right to be able to live, grow, develop and participate naturally in accordance with human dignity and dignity, and to be protected from violence and discrimination.

In addition, a lack of coordination was also seen from several SKPD who did not understand well the main tasks and functions in the KLA Task Force. In addition, so many parties involved, both from the government, community, and the world in the KLA Task Force make coordination tend to be difficult to do optimally.

\section{PROFILE OF SOUTH TANGERANG CITY}

\subsection{Research Location Profile}

South Tangerang City is a city located in Tatar Pasundan Banten Province, Indonesia. The city is located 30 $\mathrm{km}$ west of Jakarta and $90 \mathrm{~km}$ southeast of Serang, the capital of Banten Province. Tangerang Selatan consists of 7 sub-districts, which are further divided into 54 sub-district and 5 villages. Based on Law Number 51 of 2008 , South Tangerang consists of 7 (seven) districts: (1) Serpong with an area of 2,404 Ha; (2) North Serpong with an area of 
1,784 Ha; (3) Ciputat with an area of 1,838 Ha; (4) East Ciputat with an area of 1,543 Ha; (5) Pondok Aren with an area of 2,988 Ha; (6) Pamulang with an area of 2,682 Ha; (7) Setu with an area of 1,480 Ha.

The South Tangerang City Government borders the City of Tangerang in the north, Bogor Regency (West Java Province) in the south, Tangerang Regency in the west, and the Jakarta Special Capital Region in the east. In terms of population, South Tangerang is the second largest city in Banten Province after the City of Tangerang and the fifth largest in the Greater Jakarta area after Jakarta, Bekasi, Tangerang, and Depok. The area of South Tangerang City is the result of the expansion of the Tangerang Regency.

South Tangerang is located in the eastern part of Banten Province, which is at coordinate points 106'38 '$106^{\prime} 47^{\prime}$ East Longitude and 06'13'30 '- 06'22'30' South Latitude. The area of Tangerang Selatan City is crossed by Kali Angke, Kali Pesanggrahan, and Cisadane River as the administrative boundaries of the city to the west. The geographical location of South Tangerang, which borders DKI Jakarta Province on the north and east, provides an opportunity for South Tangerang City as one of the buffer zones of DKI Jakarta province, in addition to being an area that connects Banten Province with DKI Jakarta. In addition, South Tangerang is also one of the regions that connect Banten Province with West Java Province.

Furthermore, the author will explain the Pure Participation Rate (APM) and the Gross Enrollment Rate (APK) according to the level of education in South Tangerang City which will later relate to Tangerang City which has become a Decent City for children where one of them is based on the APM and APK that the child can school. More specifically, the APM and APK figures will be explained in Table.1.1 about the APM and APK below:

Table-1.1. Pure Participation Rate (APM) and Gross Participation Rate (APK) According to Education Level in South Tangerang City

\begin{tabular}{l|l|l|l|l}
\hline \multirow{2}{*}{ Educational level } & APM & \multicolumn{2}{l}{ APK } \\
\cline { 2 - 5 } & $\mathbf{2 0 1 5}$ & $\mathbf{2 0 1 4}$ & $\mathbf{2 0 1 5}$ & $\mathbf{2 0 1 4}$ \\
\hline SD & 98.88 & 98.33 & 113.11 & 108.36 \\
\hline MI & 84.81 & 76.48 & 87.88 & 86.65 \\
\hline SMP & 79.61 & 63.39 & 94.24 & 71.38 \\
\hline Source: BPS Data for South Tangerang City 2015 &
\end{tabular}

From the table above shows that NER and GER are seen from Primary Schools (SD), Madrasah Iftidyah (MI) to Junior High Schools (SMP) have increased. For the 2014 primary school APM was 98.33 and in 2015 it was 98.88. Next can be seen in the table above. Whereas for the data the number of residents of Tangerang City, based on data from the Central Statistics Agency, will be mentioned below this table:

Table-1.2. Number of Population in South Tangerang City 2010 - 2016

\begin{tabular}{|c|c|c|c|c|c|c|c|}
\hline \multirow{2}{*}{ districts } & \multicolumn{7}{|c|}{ Number of Population (Soul) } \\
\hline & 2010 & 2011 & 2012 & 2013 & 2014 & 2015 & 2016 \\
\hline Setu & 66667 & 69391 & 72170 & 75002 & 77881 & 80811 & 83777 \\
\hline Serpong & 138177 & 144378 & 150736 & 157252 & 163915 & 170731 & 177677 \\
\hline Pamulang & 287955 & 296915 & 305909 & 314931 & 323957 & 332984 & 341967 \\
\hline Ciputat & 193369 & 199807 & 206293 & 212824 & 219384 & 225974 & 232559 \\
\hline $\begin{array}{l}\text { Ciputat } \\
\text { Timur }\end{array}$ & 179792 & 184391 & 188957 & 193484 & 197960 & 202386 & 206729 \\
\hline $\begin{array}{l}\text { Pondok } \\
\text { Aren }\end{array}$ & 305073 & 316988 & 329103 & 341416 & 353904 & 366568 & 379354 \\
\hline $\begin{array}{l}\text { Serpong } \\
\text { Utara }\end{array}$ & 127471 & 134232 & 141237 & 148494 & 155998 & 163755 & 171749 \\
\hline $\begin{array}{l}\text { Kota } \\
\text { Tangerang } \\
\text { Selatan }\end{array}$ & 1298504 & 1346102 & 1394405 & 1443403 & 1492999 & 1543209 & 1593812 \\
\hline
\end{tabular}


The establishment of an autonomous city of South Tangerang or formerly called Cisera which is included in Banten Province, Indonesia emerged since 1999. But the absence of an agreement between the DPRD and the Tangerang Regency Government regarding the number of sub-districts that will be incorporated in this autonomous city hampers the formation process. Most of the people living in Ciputat, Pamulang, Serpong, Cisauk, and Pondok Aren sub-districts want to escape from Tangerang Regency. Another consideration is the aspect of community service and the Regional Original Revenue (PAD) of the six sub-districts is very large, namely 309 billion per year or 60\% of the PAD in all Tangerang Regency.

Finally on September 29, 2008, Act No. 51 of 2008 concerning the Establishment of the City of South Tangerang through the DPR-RI Plenary Session, with the district coverage area. Setu, Serpong, Serpong Utara, Pondok Aren, Pamulang, Ciputat, and Ciputat Timur join in an autonomous city called South Tangerang City. The border area of South Tangerang City is to the north, namely the border between Tangerang City and the Special Capital Region of Jakarta. In the south is the border of West Java Province, namely Bogor Regency and Depok City. In the west, Tangerang Regency and the East borders the West Java Province, namely the City of Depok and the Special Capital Region of Jakarta. For further information, the writer will explain the literature review or literature in the discussion on the Development of South Tangerang City Regional Government Policy viewed from the concept of public policy review below.

\section{LITERATURE REVIEW}

In this paper, the author will describe the concept of public policy development from Marlowe theory in Wicaksono (2006) said that policy is an attempt to create or engineer a story in order to secure the goals of the engineer. The term policy contains the same meaning as the notion of wisdom, as expressed by James in Wahab (2005) who formulates Wisdom as a behavior of a number of actors (officials, groups, government agencies) or a series of actors in a field certain activities. Friedrich in Winarno (2012) views the policy as a direction of action proposed by a person, group, or government in a particular environment that provides obstacles and opportunities to the proposed policy to use and overcome in order to achieve a goal or realize a goal or a specific purpose. According to Habermas in Parson (2005) public understanding is: "As a space that is free from economic and business intervention, and space where there is a clear boundary between public and private space as a space that encompasses the world of business and commerce where the scope of private life is far wider than those understood and developed in Britain (Britain) and America ".

Various problems in government in the framework of development can be solved through a public policy. Nugroho (2003) said that things that were decided by the government were not to be done or left unchecked. For this reason, Public Policy does not always have to be in the form of legislation, but can be in the form of unwritten rules but agreed upon. In simple terms that public policy is every decision made by the state, as a strategy to realize the goals of the country. Public policy is a strategy to usher in the early community, to enter the community during the transition period, to go to a society that is aspired. Public policy taken by private organizations and government institutions must represent the voices of the public itself, even though in reality so many desires must be carried out. For this reason, several steps must be taken before taking a policy and Nugroho (2003) said that there are 3 stages of Public Policy, namely: (1) Policy Formulation; (2) Policy Implementation; (3) Policy Evaluation.

Policy development usually in policy theory is an implementation step or commonly referred to as an implementation of a program involving policymaker efforts to influence the behavior of executing bureaucrats to be willing to provide services and regulate the behavior of the target group (Subarsono, 2006). According to Metter and Horn in Wahab (2005) formulates the implementation process as: "Actions taken by individuals or officials or groups of government or private sector directed at achieving the goals outlined in the decision wisdom. Development of public policy according to Nugroho in Public Policy (2011) 
that the implementation of policies in principle is a way for a policy to achieve its objectives. Meanwhile, Abidin (2012) explained that: "The implementation of a policy is basically a multi-organizational transformation. Therefore, the implementation strategy relates the interests that are accommodated, the more likely a policy is successfully implemented. "The following will be discussed further about the various variables involved in policy implementation through the following theories:

Model Policy Development George C. Edward III called the implementation of public policy with Direct and Indirect Impact on Implementation. In the approach applied by Edward III, there are four variables that determine the success of a policy, namely: (1) Communication. There are three indicators that can be used (or used) in measuring the success of the communication variables mentioned above, namely: (a) Transmission; (b) Clarity; (c) Consistency. The second is Resources. Where consists of several elements, namely: (a) Staff; (b) Information; (c) Authority; (d) Facilities. The third is Disposition, namely the important things that need to be observed in the variable disposition, according to George C. Edward III, are: (a) Appointment of Bureaucrats; (b) Incentives. And the fourth is the bureaucratic structure. Two characteristics, according to Edward III, which can boost the performance of a better bureaucracy/organization structure towards (a) Conduct Standard Operating Procedures (SOPs); (b) Carry out Fragmentation (Agustino, 2008).

Based on the explanation above, it can be concluded that the implementation of a policy is strongly influenced by the existence of good and clear communication between individuals and related institutions, both those who are executors and policy targets; fulfillment of needed resources; good implementor attitude or behavior; and a dynamic and flexible bureaucratic structure in the sense that it is not rigid or convoluted. Agustino (2008) explained that the approach model formulated by Metter and Horn is called A Model of The Policy Implementation. This implementation process is an abstraction or performance of a policy implementation which is basically intentionally carried out to achieve high public policy implementation performance that takes place in a variable relationship. This model assumes that policy implementation runs linearly from available political decisions, implementers, and public policy performance. There are six variables according to Metter and Horn, which affect the performance of public policies as follows (Agustino, 2008).

Policy Size and Purpose. The performance of policy implementation can be measured if the success rate is-and-only-if the size and objectives of the policy are realistic with socio-culture at the level of implementing the policy. When the size of the policy or policy objective is too ideal (even too utopian) to be implemented at the citizen level, it is rather difficult to realize public policy to the point that it can be said to be successful such as:

1. Resources. The success of the policy implementation process depends on the ability to utilize available resources. Humans are the most important resource in determining the success of the implementation process. But outside human resources, other resources that need to be taken into account are financial resources and time resources.

2. Characteristics of Implementing Agents. The focus of attention on implementing agencies includes formal organizations and informal organizations that will be involved in implementing public policies. This is very important because the performance of public policy will be very much influenced by the characteristics that are appropriate and suitable with the executing agents.

3. Attitudes and trends. The attitude of acceptance from executing agents will greatly affect the success or failure of public policy performance. This is very likely to occur because the policy implemented is not the result of the formulation of local residents who are familiar with the problems and problems they feel. But the policy that the implementer will implement is a "top-down" policy that is very likely the decision makers never know (not even able to touch) the needs, desires, or problems that the citizens want to solve. 
4. Communication between Organizations and Implementing Activities. Coordination is a powerful mechanism in the implementation of public policy. The better the coordination of communication between the parties involved in an implementation process, then the assumption of errors will be very small to occur, and vice versa.

5. Economic, Social and Political Environment. The last thing that also needs to be considered to fulfill the performance of the implementation of public policy in the perspective offered by Metter and Horn is, to what extent the external environment contributes to the success of public policies that have been implemented. A non-conducive social, economic and political environment can be the culprit in the failure of policy implementation performance. Therefore, efforts to implement policies must also pay attention to the conducive conditions of the external environment.

\section{METHODS}

In this study, the authors use a qualitative approach that is descriptive, which explains the phenomenon in depth through data collection. This type of research provides an overview, an accurate explanation objectively about the actual state of the object under study. In this study to determine the informants that can be explored accurate information using purposive sampling technique that is by selecting resource persons who really know the internal and external conditions of the South Tangerang City Government Office. So that it will provide proper input on the implementation of the Regulation of the Minister of Women's Empowerment and Child Protection of the Republic of Indonesia Number 11 of 2011 concerning the Development Policy of Decent Districts / Cities in KLA in South Tangerang City. The informants selected from this study came from Tangerang City Government Office employees and this study also used accidental sampling technique which was taken from the people who participated in the Policy Implementation of Decent City of South Tangerang Children.

Informants are people who really know or are actors who are directly involved with research problems. This informant must have a lot of experience about research and can provide views on the values, attitudes, processes, and culture that are the background of local research. Data Analysis Techniques uses a theoretical approach from Miles and Huberman (1992) qualitative data analysis consists of (1) Data reduction is defined as the process of selecting, formulating, paying attention to simplification, abstracting and rough data information arising from written records in the field. Data reduction is a form of analysis to sharpen, classify, direct, dispose of unnecessary and organize data in such a way that conclusions can finally be drawn and verified; (2) Presentation of data on a set of information that has been arranged in an integrated and understood manner that gives the possibility of drawing conclusions and taking action; (3) Draw conclusions on verification of various data findings obtained during the research process.

\section{RESULT AND DISCUSSION}

The results and discussion in writing researchers use public policy development theory according to Metter and Horn. Because there is a match between the problems contained in the identification of problems with what is described in the theory. There are six variables according to Metter and Horn, which affect the performance of public policies as follows Agustino (2008) namely: (1) Size and Purpose of Policy; (2) Resources; (3) Characteristics of Implementing Agents; (4) Attitudes and trends; (5) Inter-Organizational Communication and Implementing Activities; (6) Economic, Social and Political Environments.

First, Policy Size and Purpose. The South Tangerang City Government began launching the KLA Development Policy since 2011 through strengthening political commitment shown by forming the KLA Task Force. The purpose of the KLA Development Policy in South Tangerang City is in accordance with what is stated in the Minister of Women's Empowerment and Child Protection Regulation No. 11 of 2011 
concerning Development Policies for Decent Cities / Children, to build district / city government initiatives that lead to efforts to transform the Convention on the Rights of the Child from the legal framework into definitions, strategies and development interventions, in the form of: development policies, programs and activities aimed at the fulfillment of children's rights, in a district / city area.

Second, Resources consist of human resources, financial resources, and time resources. Human resources in the implementation of KLA development policies in South Tangerang City are sufficient in quality and quantity. Financial resources come from the APBD, which is sufficient for the implementation of the KLA development policy, but it is still considered limited or has not fully met the needs for socialization activities and also for the development of children's rights cluster facilities and infrastructure. And for time resources, the South Tangerang City Government's own policy does not have a clear time target because the policy must be sustainable.

Third, the characteristics of implementing agents in the KLA Development Policy must be synchronized with each other, all aspects must be involved. In addition to coordination, which is an obstacle, the weak socialization of the subdistrict or urban village (kelurahan) activities? In addition, the KLA Task Force strengthening is also felt to be less than optimal because SKPD initiatives are still lacking. The implementing agency for KLA Development Policy in South Tangerang City has not been maximized.

Fourth, the implementer's attitudes. The response or response of the implementing agency of the KLA Development Policy in South Tangerang City is generally good and mutually supportive. However, the implementation of the policy for some implementing agencies is also expected not to pursue mere appraisal or appreciation. The KLA Policy Implementation in South Tangerang City will be difficult to materialize if all implementing agencies do not have the same view of the importance of fulfilling children's rights in the regional development system.

Fifth, Effective communication between organizations and implementing activities. The KLA Development Policy is a policy of the central government that is carried out by the district/city Regional Government involving all elements, starting from the local government, the business world, and the community, therefore coordination plays a very important role. Because coordination is needed so that the KLA Development Policy can run and not overlap the duties of each stakeholder so that the main tasks and functions of each party concerned must understand.

Sixth, the political, social, economic, and environment. Whereas the general economic environment supports the implementation of the KLA Development Policy in the City of South Tangerang, while for the social environment hampers the implementation process of the KLA Development Policy because of the characteristics of the urban community who are individualistic and less caring so they tend to be less active. However, political elite groups, participants of implementing agencies ranging from stakeholders, businesses, and communities strongly support this policy.

Conformity that arises, among others, is seen from the indicators contained in the process of implementing public policies, especially the implementation of Child-Friendly District / City Development Policy (KLA) in South Tangerang City. Because the implementation of this policy requires communication between the government of South Tangerang City and SKPD whose duties and functions are relevant to the problems of children, the Organization / Forum / Group of Children and other relevant institutions, and of course the people of South Tangerang City. These efforts are intended to realize the Decent City of Children in South Tangerang City. 


\section{CONCLUSIONS AND RECOMMENDATIONS}

\subsection{Conclusions}

The development of the District / City Development Policy (KLA) in the City of South Tangerang has generally been going well, judging by the achievement of these policy objectives with the fulfillment of most of the rights of the child based on the Convention on the Rights of the Child (CRC), although there are a number of things that still need improvement.

The best fulfillment of children's rights clusters in the implementation of the District / City Development Policy (KLA) in South Tangerang City based on the Convention on the Rights of the Child (CRC) is basic health and welfare, as seen from the large number of breastfeeding facilities and breast milk corners, the high percentage of complete basic immunizations for children, the low prevalence of malnutrition in children under five, low infant mortality rate (IMR), and the achievement and achievement of ARHCIC (Adolescent Reproductive Health Counseling Information Center) as reproductive and mental health institutions for children in South Tangerang City.

\subsection{Recommendations}

Based on the results of research, the recommendations are as follows: (1) Improving synchronization by equating the view of the urgency of fulfilling children's rights for SKPD; (2) Conduct more incentive communication between Child Friendly City Task Force and periodic monitoring so that the implementation of KLA Development Policy in South Tangerang City is more optimal. Also by following up on every decision on the results of the coordination meeting; (3) Developing shelter houses by the South Tangerang City Government so that the local government can provide guidance and rehabilitation for street children. As well as by conducting a more even socialization, because no matter how good the KLA Development program or activity should have been echoed as much as possible so that it can be felt by children and the community, so that community awareness and active role can also be improved. The socialization and strengthening of the Child Protection Task Force (Task Force PA) at the RW level also need to be done so that they can play an active role in preventing child abuse and can be recognized by the community's roles and functions. This study is one of the very few studies which have investigated the child-friendly city

Funding: This study received no specific financial support.

Competing Interests: The author declares that there are no conflicts of interests regarding the publication of this paper.

\section{REFERENCES}

Abidin, S.Z., 2012. Public policy. Jakarta: Sakemba Humanika.

Agustino, L., 2008. Basics of public policy. Bandung: CV Alfabeta.

Miles, B.M. and M. Huberman, 1992. Qualitative data analysis: Resource book about new methods. Jakarta: UIP.

Nugroho, R.D., 2003. Public policy: Implementation and evaluation formulations. Jakarta: PT Elex Media Komputindo.

Parson, W., 2005. Public policy: An introduction to the theory and practice of policy analysis. Jakarta: Prenada Media.

Subarsono, 2006. Public policy analysis: Concepts, theories, and applications. Yogyakarta: Learning Library.

Wahab, A.S., 2005. Policy analysis: From the formulation to the implementation of state policy. Jakarta: Bumi Aksara.

Wicaksono, K.W., 2006. Government administration and bureaucracy. Yogyakarta: Graha Ilmu.

Winarno, B., 2012. Public policy, theory, and process. Jakarta: Media Pressindo.

Views and opinions expressed in this article are the views and opinions of the author(s), International Journal of Social and Administrative Sciences shall not be responsible or answerable for any loss, damage or liability etc. caused in relation to/arising out of the use of the content. 